\title{
Managing Innovation: Accelerating the Development of Clean Coal Technology
}

\begin{abstract}
Coal gasification technology concerns the clean, efficient utilization of coal, providing a core solution to address its negative environmental image and impact. Presently, China is pursuing the development of coal gasification technology despite industry setbacks, limited progress and elusive solutions due to limited specialty materials, technological shortfalls and intellectual expertise. The most prominent challenges to overcome include unbalanced research and project scale development issues followed by an excessive emphasis on equipment manufacturing rather than responsible management practices. The ENN Group explored these industry shortcomings to develop a comprehensive management philosophy that is specifically tailored to overcome these fundamental hurdles. Such innovative solutions include the Centralized Innovation Camp, TRIZ (Theory of Inventive Problem Solving) training, Extensive Alliance Network and enhanced process management, focusing upon engineering, quality assurance and process efficiency with the overall objective of industrial scale application. As a result, ENN's Clean Coal Technologies include: Coal Hydrogasification, Supercritical Coal Gasification, Catalytic Coal Gasification and Underground Coal Gasification, having successfully completed all pilot plant testing requirements and the construction of demonstration commercial units.
\end{abstract}

Keywords: coal technology, coal gasification, innovation, management, clean, ENN

\section{Introduction}

China is the largest producer and consumer of coal

Manuscript received December 2, 2013; accepted May 2, 2014

Ya-juan Sun ( $₫)$, Guo-qing Wang, Yan Wang, Ning Zhang, Zhen-qi Zhu State key Laboratory of Coal-based Low Carbon Energy, ENN Science and Technology Development, Co., Ltd., Langfang, Hebei 065001, China

Email: nyyjy@enn.cn worldwide, with exploitable fossil fuel reserves in excess of $95 \%$ and coal accounts for $70 \%$ of China's primary energy consumption. While the nation's coal supply remains adequate for the next two decades, the environmental cost of its use has begun to take its toll, resulting in atmospheric pollution and greenhouse gas emissions. In addition, China's low energy network efficiency and supply chain reliability issues present constant challenges for sustainable development. As the country enters the midterm industrialization stage, coal consumption has surpassed the Gross Domestic Product (GDP) growth, adding excessive stress to the security of both the coal and chemical industry. To meet China's $\mathrm{CO}_{2}$ emissions reduction target goal of $40 \%-45 \%$ by 2020 , clean coal and alternative cost-effective energy technologies must be developed quickly to minimize the overall economic and environmental impact.

Coal gasification technology remains a critical factor in safeguarding the environment alongside the efficient utilization of coal. Although commercial coal gasification technologies exist, prominent shortcomings have emerged as well. The conventional coal gasification process involves a two-step approach: gasification and methanation. During the process of high temperature gasification (over $1,000^{\circ} \mathrm{C}$ ), water gas shift reaction, low temperature methanol washing process and methanation reaction, the negative factors such as high reaction temperature, difficulties in gas purification, high energy consumption, high investment, high requirements for equipment, as well as environmental pollution problems are difficult to avoid. The situation directly led to Research and Development (R\&D) of the $3^{\text {rd }}$ generation coal gasification technologies, mainly represented by Catalytic Coal Gasification (CCG). CCG employs a one-step approach to produce methane from coal, which means catalytic coal gasification, water gas shift reaction and methanation reaction take place in one reactor by raising pressure, lowering temperature and adding a small amount of catalysts. The advantages of CCG technology are ease of operation, relatively small investment and less sewage. 
As China is promoting R\&D and industrialization of coal gasification technology, obstacles such as lack of innovation, disconnection of R\&D and engineering, and insufficient attention to the fine management continue to hinder the progress. Taking these issues into account, the ENN Energy Institute developed an innovative, constructive solution to promote technology development focused on accelerated field applications.

\section{Management innovation}

\subsection{Scientific and efficient methods}

Albert Einstein's equation, $\mathrm{E}=\mathrm{MC}^{2}$ establishes the relationship between matter (M), energy (E) and squared speed of light $\left(\mathrm{C}^{2}\right)$ concluding the huge impact of speed on energy. Samsung's Galaxy Tablet took nine months from the initial concept to the final product, surpassing the three-year estimates. Many cases show that, scientific leaps of innovation accelerate the speed of research and development.

2.1.1 Accelerated research and development: centralized innovation camp

Drawing from Samsung Corporation's product innovation and management success, ENN developed the Centralized Innovation Camp (CIC), a specialized platform to expedite process development and integration. At CIC, individuals can collaborate well using centralized resources to address specific technical problems, providing real-time solutions, full cycle coordination, prioritized support, parallel work and advanced preparation. This equates to work accomplishments at reduced time frames, achieving quality results at minimum cost.

\subsubsection{Innovative tools}

Researchers equipped with adequate resources can effectively find solutions to scientific problems. Using dialectical thinking, TRIZ (Theory of Inventive Problem Solving) can assist researchers to logically think and overcome mental barriers, dynamically improving their ability to analyze problems and increase research efficiency. In addition to TRIZ, other developmental tools include: Value Innovation (VI), Group Value Engineering (GVE) and Design for Six Sigma (DFSS), etc.

In 2010, ENN commenced TRIZ training for 30 engineers who in-turn qualified 100 researchers. TRIZ theory enabled ENN researchers to resolve technical obstacles in the fields of CCG, Underground Coal Gasification (UCG) and waste water treatment; generating 26 patents, 4 scientific publications and corporate technical improvements, with a total economic benefit in excess of 5.8 million $\mathrm{CNY}$.

\subsubsection{Extensive alliance network}

The scientific advances in research and technology development have resulted in highly differentiated but integrated innovations; as a result, the traditional boundaries segregating academic disciplines have slowly dissolved. As the complexity of innovation continues, companies must remain flexible to successfully adapt against market trends and consumer shifts in demand.

Developing partnerships across universities, research institutes and industrial sectors was a means to accelerate technical innovation and enhance a company's competitive edge. Using the internet to develop a virtual network of cooperation and innovation, the European Union (EU) established multiple "Virtual Centres of Excellence", forming a "Joint Research Network" requiring industrial manufacturers, market developers and consumers to oversee collective projects from concept to final assembly phase. This action dramatically reduced research and development risk while expediting product cycles.

ENN's extensive collaboration network offers significant contributions to the advancement of clean coal technology. This stringent selection criterion for technical cooperation is based upon extensive evaluation studies and a clear strategic direction. The Department of Alliance searches for worldwide partnerships with compatible strategic perspectives and overall resource capacity. The Alliance Preparatory Committee and Technical Committee are responsible for establishing the terms of contract, appraising plan details and technical routes to reduce overall collaboration risks. Life cycle alliance management offers a complete supervisory control system and is enforced from the initial planning stage to final assessment period, paralleling cooperation points in advance. One specific example is cooperating with the Industrial Design Institute at the pilot stage thus reducing future industrialization cycle time.

\subsubsection{Setting technology directions and priority focus}

Technology Readiness Levels (TRLs) are used to assess the maturity of evolving technologies and classify them on a scale ranging from basic to mature applications (Mankins, 1995). Using Table 1, 13 TRLs reflecting the evolvement from report to payback are used to classify Chinese technology advancements (See Table 2). ENN is focused upon technology integration and innovation, specifically, TRL 4-9 (13 TRLs in China) or TRL 4-7 (9 TRLs); where fundamental research and commercialization are depend upon partnerships or existing research achievements.

2.2 Process management, rational decision-making and timely corrective actions

The development of clean coal technology is of strategic 
Table 1

Nine TRLs in the National Aeronautics and Space Administration (NASA)

Basic technology research Technology development

(TRL 1-2)
(TRL 3-5)
System/subsystem development

(TRL 6-9)
Research to prove feasibility

(TRL 2-4)
Technology demonstration

(TRL 5-7)
System test,

launch and operations

(TRL 8-9)

\begin{tabular}{|c|c|c|c|c|c|c|c|c|}
\hline$\overline{\text { TRL1 }}$ & TRL2 & TRL3 & TRL4 & TRL5 & TRL6 & TRL7 & TRL8 & TRL9 \\
\hline
\end{tabular}

Table 2

Thirteen Technology Readiness Levels (TRLs) within the ENN Energy Research Institute

\begin{tabular}{lccccccc}
\hline & $\begin{array}{c}\text { Laboratory studies } \\
(1-4)\end{array}$ & $\begin{array}{c}\text { Lab test } \\
(5-6)\end{array}$ & $\begin{array}{c}\text { Pilot test } \\
(7-8)\end{array}$ & $\begin{array}{c}\text { Demon- } \\
\text { stration (9) }\end{array}$ & $\begin{array}{c}\text { Commercialization } \\
(10-13)\end{array}$ \\
\hline 1 Report & 2 Solution & 3 Function & $\begin{array}{c}\text { 4 Simu- 5 Proto type 6 Example } \\
\text { lation }\end{array}$ & $\begin{array}{c}\text { 7 Envir- 8 Product } \\
\text { onment }\end{array}$ & 9 System & 10 Sales & $\begin{array}{l}11 \text { Profit } \\
\text { and loss }\end{array}$ \\
\hline
\end{tabular}

importance to meet the nation's continuing energy demands. There are daunting challenges to overcome ranging from initial concept to commercial applications. As technology evolves from theoretical research to laboratoryscale development, then pilot-scale validation before industrial demonstration; these distinct phases correspond to specific TRLs. During the pilot and lab-scale development phase, project management is difficult due to process uncertainties, key engineering equipment design and manufacturing support, hence the need for supervisory direction. It proposed the "Complexity Theory of Project Management" (Winter, Smith, Cooke-Davies, \& Cicmil, 2006), and it answers the question posed by Whitty and Maylor (2009) of how to approach a complex project. It shows the project complexity mapping in five dimensions (Marshall \& Rousey, 2009). R\&D project management has a similar complexity, it needs to find the right way to improve management efficiency. ENN is exploring multiple pathways to adapt market fluctuations and technology advancements, mitigating risks while remaining aware of project feasibility and expansion, particularly in laboratory and pilot-scale development.

2.2.1 Establish immediate scientific decision-making during technology development, actively respond to market demands and shorten development cycles

Research and development is focused on laboratory, pilotscale and commercialization phases once a technological direction is determined. These challenges feature extensive development cycles, connecting basic achievements with technical innovations under the stringent guidelines of project management. Key process decisions impact the overall development cycle which are scientifically critical. First, establish a committee composed of experts in marketing, technology, engineering, procurement and finance with the authority to make executive decisions. Second, establish a tier-level platform for technology and business related decisions. Third, design prior communication mechanisms to make decision making understandable to everyone pertaining to issues discussed, leading to an efficient consensus and implementation of agreed terms. Within laboratory and pilot scales, "projects" are used to classify management stages, milestones, and quantify the risks involved in technical solutions and engineering designs. At this stage, the decision-making process is focused on technology, with the majority of participants being engineers and technicians. During cross-phase decision-making, third parties provide input concerning major construction and financial investment. Within this stage, the decision-making process shifts its focus to business transactions, where marketing, management, technology, engineering and finance professionals negotiate a workable, realistic solution.

2.2.2 Strengthening management controls for specific sections of engineering and technology: ensuring quality solutions by anticipating problems

As an emerging technology, clean coal encompasses a diversity of factors such as equipment, materials and industry standards. The relationship of sectors such as conceptual test unit design, non-standard equipment manufacturing and installation, support facility construction and experimental optimization is such that any discrepancy has the potential to cause significant losses to the overall project. Based upon these features, process management focuses on these key aspects:

(1) Effective Management Planning, Cooperation Based Task Division: the involvement of multiple professionals demands an emphasis on management processes with a clear allocation of individual tasks and long term cooperation. Such ambitious project management and planning involves grade and rolling plans. First, achievement milestones are established to stipulate the overall project scope and assign a director with executive authority to 
conduct planning reviews, resolve management issues and adjust programs to ensure overall cooperation and success.

(2) Project Tracking and Problem Solving: technology development is often plagued with unexpected problems, overcoming these technical hurdles and engineering specifications determine the overall progress of innovation. Project management oversight tracks and evaluates everyday progress, providing feedback and identifies potential problems before they materialize into delays.

(3) Stringent Key Section Reviews: the review staff, a panel of industry experts and professionals, maintains a constant, strict oversight of specific sections involving technology, manufacturing and engineering design using established company standards. This ensures that innovations test reliably, minimize risk, are dependable, minimize waste and achieve project targets safely.

\section{Innovation practice}

\subsection{Case I: coal hydro-gasification}

Coal hydro-gasification is a process where pulverized coal reacts with hydrogen at $800^{-} 1,000^{\circ} \mathrm{C}$ under $5-10 \mathrm{MPa}$ of pressure to generate methane, light oil and char at elevated rates efficiently. In addition, the cogeneration of market grade light oil by-products renders it more economical in comparison to alternative gasification processes.

In the 1980's, the United States, Great Britain and Japan invested extensive scientific resources and funding to develop coal gasification technology and equipment. As Japan advanced to construct a five ton-per-day Process Development Unit (PDU), worldwide government sponsorship diminished due to the decline of natural gas prices. In 2005, the United States restarted its research program equipped with the remaining falling bed test and concept design for kiloton-scale production.

In 2012, after a comprehensive review of international coal-to-methane technologies, ENN resumed hydro-gasification research, a task stipulated under the national "863 plan", producing natural gas and commercially valuable oils from coal. As technical issues were identified, ENN utilized its resources to minimize risk; modifying an advanced coal conveyor, a hydrogen combustion system, a high temperature hydrogen-oxygen injector and an independently developed gasifier. As these challenges were systematically resolved, project milestones were accelerated ahead of schedule. Meanwhile, designs for a five to ten ton-per-day PDU were completed, under construction and would commence operation by late 2014 . Future projects in development include a fifty ton pilot scale plant in five years, large scale reactor projects and one thousand ton commercial demonstration units.

The hydro-gasification process efficiently utilizes coal through grading, quality selection and cascaded utilization and is regarded as one of the most advanced clean energy technologies which incorporate low grade, highly volatile, sub-bituminous coal-accounting in excess of $40 \%$ of China's reserves-as a potential resource.

\subsection{Case II: supercritical coal gasification}

Supercritical Water (SCW) Coal Gasification uses specific temperature and pressure conditions, gas solubility, low grade coal oxidation heat and the mass transfer characteristics of organic matter for a series of catalytic gasification and methanation reactions within the same vessel. The valuable end products include methane, hydrogen gas and industrial oils. This high efficiency process bypasses the drying stage and carries widespread applications for utilizing low quality coal.

At present, the United States, Germany, Australia and Ireland are the leading $\mathrm{SCW}$ gasification research pioneers (see Table 3). However, critical issues such as industrial scale corrosion, abrasion problems, gas-liquid-solid multiphase flow stability and solid phase concentrated material clogging remain to be resolved.

Based upon these advantages, ENN developed its own Supercritical Water Gasification (SCWG) process to treat carbonaceous waste, high moisture lignite, municipal sludge and other non-biodegradable liquids. In addition, ENNs Energy Research Institute, in cooperation with universities, research institutions and engineering companies, made significant progress involving corrosion resistant materials, a clog-resistant reactor and heat exchangers. The extensive research data collected, coupled with successful operational experiences resulted in scaled-up pilot plant testing. Overall, ENNs pilot plant and research capabilities, particularly in proprietary self-heating and support equipment, remain on-par with world class standards.

At the conclusion of 2011, ENN constructed a pilot testing plant to remedy high concentrations of degradationresistant liquid waste. After thirty two hours of stable, continuous operation, the waste water's organic matter conversion rate exceeded $99.5 \%$; after seventy two hours of sludge treatment, the degradation rate surpassed $99.0 \%$, a volume reduction in excess of $90 \%$ with no secondary pollutants. Within seventy two hours of operation, SCW technology proved itself superior to existing methods in processing low grade coal slurry with high concentrations of lignite.

As a result of SCWG pilot testing, ENN acquired project-based data, and completed a commercial unit industrial technology package. Devoted to the development of refractory waste water and sludge technology, its future projects include a one hundred-ton-scale commercial sewage treatment processing unit.

\subsection{Case III: catalytic coal gasification}

CCG produces methane directly from coal and water vapor 
Table 3

International Research and Development Status

\begin{tabular}{|c|c|c|c|c|c|c|}
\hline Country & Company & Scale & Feed & $\begin{array}{c}\text { Processor and } \\
\text { Reactor }\end{array}$ & Products & Remark \\
\hline Australia & IER & $5 \mathrm{t} / \mathrm{d}$ (dry) & High water lignite & $\begin{array}{l}\text { Cat-HTR } \\
\text { reactor }\end{array}$ & High-value clean coal and oil & $\begin{array}{c}200 t / d \text { commercial } \\
\text { demonstration project is } \\
\text { building }\end{array}$ \\
\hline Germany & $\begin{array}{c}\text { Forschungszentrum } \\
\text { Karlsruhe Institute fur } \\
\text { Technische Chemie,FKITC }\end{array}$ & $2.4 \mathrm{t} / \mathrm{d}$ & Coal, waste biomass & $\begin{array}{l}\text { External } \\
\text { heating, } \\
\text { tubular reactor }\end{array}$ & $\mathrm{CO}_{2}, \mathrm{CH}_{4}$, and $\mathrm{H}_{2}$ & $\begin{array}{c}\text { The highest concentra- } \\
\text { tion is } 20 \%\end{array}$ \\
\hline United States & General Atomics & $10.8 \mathrm{t} / \mathrm{d}$ & $\begin{array}{l}\text { Biomass slurry, } \\
\text { military waste }\end{array}$ & $\begin{array}{c}\text { Partial } \\
\text { oxidation, } \\
\text { tank reactor }\end{array}$ & $\begin{array}{l}\text { Crude gas }\left(38 \% \mathrm{H}_{2}, 30 \%\right. \\
\left.\mathrm{CH}_{4}, 28 \% \mathrm{CO}_{2}, 4 \% \mathrm{CO}\right)\end{array}$ & $\begin{array}{l}\text { Dealing with military } \\
\text { waste, coal and biomass; } \\
\text { the highest concentration } \\
\text { is } 19 \% \text { because of coking }\end{array}$ \\
\hline Ireland & SCFI & $6 \mathrm{t} / \mathrm{d}$ & $\begin{array}{c}\text { Spent catalyst, solid } \\
\text { waste, sludge }\end{array}$ & Tubular reactor & Precious metal catalyst, $\mathrm{CO}_{2}$ & $\begin{array}{c}\text { Concentration is lower } \\
\text { than } 10 \%\end{array}$ \\
\hline
\end{tabular}

in the presence of a catalyst. Using a fluidized bed reactor, temperatures of $600^{-} 800^{\circ} \mathrm{C}$ and $3.0^{-}-5.0 \mathrm{MPa}$ of pressure, methane gas is generated at concentrations of $25 \%$. This process converts sub-bituminous coal and lignite into Substitute Natural Gas (SNG) meeting China's urgent demand for improved coal-to-methane technologies, innovations which address nature gas shortages, environmental benefits and profitable market prospects.

The original research concerning $\mathrm{CCG}$, including catalyst manufacture/recovery, amplification simulation and PDU testing, to produce methane originated in the United States in 1970. Despite proving the principle feasibility, the technology was abandoned due to the low market price of natural gas. In 2004, a separate American company, using data from the original research and development team, re-initiated the process; by 2011, a scaled up 1 ton-per-day electrical PDU was completed.

Since 2008, ENN independently researched the development of fluidized bed CCG to produce SNG. ENN's CCG technology integrates pyrolysis, gasification and coal combustion within separate stages of the same reactor. The process starts with feed coal which is pre-heated from the gasification stage exhaust and pyrolized to separate tar and methane. As combustion occurs, coal residues release gasification thermal energy, balancing overall process heat, reducing solid residence time while increasing the gasifier process capacity, minimizing energy investment and operations cost; the overall thermal efficiency is significantly improved due to indirect heat exchange within the gasifier.

At present, CCG bench-scale research to determine gasifier flow and reaction characteristics, including scaledup auto thermal fluidized bed studies, were completed. ENNs auto thermal fluidized bed was constructed using private intellectual rights; having operated PDU for over three hundred hours under elevated pressures verified pressurized fluidization, coal grading conversion, distributed oxygen introduction and indirect condensation allow- ing for preliminary design modifications for a scaled-up demonstration plant.

ENN's CCG process exhibits multiple advantages. First, the per-unit cost of single versus dual-step methane production is reduced, therefore more economical. Second, the technology is compatible with bituminous, subbituminous coal and lignite. Third, higher gasification utilization efficiency is achieved through grading conversion, combined coal pyrolysis, catalytic gasification and combustion; as methane yields increase, $\mathrm{CO}_{2}$ emissions decline. Fourth, indirect condensation avoids syngas waste water production from cooling and clean-up, unconverted gasifier steam is utilized for catalyst recovery, making the overall process environmentally friendly.

\subsection{Case IV: underground coal gasification}

UCG converts coal-based organic matter into combustible gas using thermal and chemical reactions without the necessity of coal mining. Historically, coal mining from collection, transport to consumption was a hazardous occupation, resource wasteful and ecologically destructive. UCG revolutionizes well construction, coal mining and gasification by transforming coal mines into industrial gas fields. The impact of UCG is significant, converting China's low quality coal reserves into low carbon, chemical synthesis feed gas at reduced cost, leaving ash and gangue underground and insuring national energy security.

In 1888, Russian chemist Dmitri Mendeleev proposed the concept of underground coal gasification. By the 1930s, the majority coal producing nations including the former Soviet Union, Great Britain, France, Germany, the United States and Belgium developed analogous processes. However these ceased due to the widespread use of petroleum. As the global energy crisis and demand of low carbon alternatives increased, UCG has received renewed interest. Already, China, Australia and South Africa have 
Table 4

Cross Comparison of UCG Processes

\begin{tabular}{|c|c|c|c|c|}
\hline & & ENN (China) & A company & B company \\
\hline \multirow[t]{5}{*}{$\begin{array}{c}\text { Technical characteris- } \\
\text { tics }\end{array}$} & Characteristics & $\begin{array}{l}\text { Depth of } 300 \mathrm{~m} \text {, seam thickness } 9 \mathrm{~m} \text {, } \\
\text { lignite,soft rock roof about thickness } \\
22-64 \mathrm{~m} \text {,two aquifers }\end{array}$ & $\begin{array}{l}\text { Depth of } 130 \mathrm{~m} \text {,seam thickness } \\
10 \mathrm{~m} \text {,sandstone roof,no aquifer }\end{array}$ & $\begin{array}{c}\text { Depth of } 300 \mathrm{~m} \text {,seam thickness } \\
5 \mathrm{~m} \text {,igneous rock roof,aquifer }\end{array}$ \\
\hline & Gasifier shape & “U”gasifier & CRIP & “U”gasifier \\
\hline & Gasification agent & $\mathrm{O}_{2} / \mathrm{CO}_{2}$ & Oxygen enriched air & Air \\
\hline & Technical indicators & $\begin{array}{l}\text { (Air) product gas } 0.3 \text { million } \mathrm{Nm}^{3} / \mathrm{d} \text {, } \\
\text { LHV: } 3.7 \mathrm{MJ} / \mathrm{Nm}^{3} ;\left(\mathrm{O}_{2} / \mathrm{CO}_{2}\right) \text { product } \\
\text { gas } 0.1 \text { million } \mathrm{Nm}^{3} / \mathrm{d} \text {, LHV: } \\
8.1 \mathrm{MJ} / \mathrm{Nm}^{3} \text {; last operation } 31 \mathrm{months}\end{array}$ & $\begin{array}{l}\text { Product gas } 0.25 \text { million } \\
\mathrm{Nm}^{3} / \mathrm{d} \text {, outlet pressure: } \\
0.4 \mathrm{Mpa} \text {, LHV: } 8.4 \mathrm{MJ} / \mathrm{Nm}^{3} \text {; } \\
\text { last operation two years. }\end{array}$ & $\begin{array}{c}\text { (Air) product gas } 0.25 \text { million } \\
\mathrm{Nm}^{3} / \mathrm{d} \text {, outlet pressure: }+ \text {, LHV: } \\
4.2 \mathrm{MJ} / \mathrm{Nm}^{3} \text {; last operation more } \\
\text { than two years. }\end{array}$ \\
\hline & Current state & Pre-industrialization demonstration & $\begin{array}{l}\text { Pre-industrialization } \\
\text { demonstration }\end{array}$ & $\begin{array}{c}\text { Pre-industrialization } \\
\text { demonstration, has started } \\
\text { construction }\end{array}$ \\
\hline Products \& economic & & $\begin{array}{c}0.2 \text { billion } \mathrm{Nm}^{3} \mathrm{LNG} / \mathrm{a} \\
1.98 \mathrm{CNY} / \mathrm{Nm}^{3}\end{array}$ & $\begin{array}{l}\text { Synthetic oil: } 10,000 \text { barrels/d } \\
\text { \$60/barrel }\end{array}$ & $100-140 \mathrm{MW}$ \\
\hline Strengths & & $\begin{array}{l}\mathrm{O}_{2} / \mathrm{CO}_{2} \text { gasification process is } \\
\text { proprietary technology, suitable to } \\
\text { produce methane, single gasifier } \\
\text { production high }\left(0.5 \mathrm{million} \mathrm{Nm}^{3} / \mathrm{d}\right)\end{array}$ & $\begin{array}{c}\text { Reference Anglin experience, } \\
\text { with coiled tubing from oil } \\
\text { industry to realize active control, } \\
\text { low drilling cost }\end{array}$ & $\begin{array}{l}\text { Purchase the former Soviet } \\
\text { Union technology, air } \\
\text { gasification is easy to } \\
\text { realize, single gasifier } \\
\text { production is high }\end{array}$ \\
\hline Weakness & & $\begin{array}{l}\text { More wells, high cost of gasifier, } \\
\text { high environmental risk }\end{array}$ & $\begin{array}{l}\text { Recovery for single gasifier is } \\
65 \% \text {, for multi-gasifiers is just } \\
35 \% \text {; single gasifier production is } \\
\text { low }\left(0.25 \text { million } \mathrm{Nm}^{3} / \mathrm{d}\right)\end{array}$ & $\begin{array}{l}\text { More wells, high cost of } \\
\text { gasifier, high } \\
\text { environmental } \\
\text { risk }\end{array}$ \\
\hline
\end{tabular}

established continuous operational stations while the United States, Canada, Pakistan and Vietnam are making preparations to launch independent UCG projects.

In 2006, ENN developed an UCG technology using the first Chinese no-shaft gasification demonstration base in Ulanqab city, Inner Mongolia. In October 2007, this initial unit continuously produced gas at a stable rate of 0.3 million $\mathrm{Nm}^{3} / \mathrm{d}$ for thirty months, generating 3.82 million $\mathrm{kWh}$ of power.

During the production of synthesis gas, ENN made exceptional progress on industrialization experiments using oxygen and $\mathrm{O}_{2} / \mathrm{CO}_{2}$ underground gasification. Using American CRIP gasification knowledge and Russian vertical well \& U shape gasifiers (Table 4). ENN derived an advanced shape design that increased reliability and usefulness after mastering reverse combustion linked wells, directional drilling, reverse combustion and the forward gasification process with multi-point agent injections. As its operational experience with directional-underground drilling, dredge methods, preliminary roof water control and groundwater pollution prevention developed, ENN modified its strip or face-shaped gasifier based upon local field conditions. In 2012, ENN launched the "Underground Coal Gasification to Produce 0.2 billion $\mathrm{NM}^{3} / \mathrm{a}$ Liquefied Natural Gas" project. Preparatory work was approved by the National Energy Administration.

\section{Conclusions}

The results illustrate that by combining scientific/technical innovations with effective management practices, the efficiency of advanced technology progress is increased. By reducing the research and development cycle timeline, access to innovation can improve equally among the growth sections at an accelerated rate. Empowering process management keeps project development in-line with corporate objectives, minimizes waste and increases productivity. Integrating technological innovations, with market conditions can enhance the quality of research, engineering and development to the extent of promoting the establishment of an entire industrial production chain.

The rapid innovation of clean coal engineering technology research has led to theoretical and practical innovations in project management. Results demonstrate that regular effective management measures improve the efficiency of the research and development cycle.

Acknowledgements The authors would like to thank ENN Energy Research Institute's four project teams and their dedication to developing coal gasification technology; and colleagues from the Project Management Department. We wish to thank all the experts who contributed to this research. We would also wish to thank all of the experts and cooperators who contributed to this research, and Xudong Qi, San Zhou, Yushan Yan and Eric Villavicencio, who translated this paper into English. 


\section{References}

Mankins, J.C. (1995). Technology Reading Levels: A white paper. Advanced Concepts Office, Office of Space Access and Technology, NASA, April 6, (1995)

Marshall, K.R., \& Rousey, S. (2009). Guidance for transportation project management. Washington, DC: The National Academies Press
Whitty, S. J., \& Maylor, H. (2009). And then came Complex Project Management. International Journal of Project Managememt, 27(3), 304-310

Winter, M., Smith, C., Cooke-Davies, T., \& Cicmil, S. (2006). The importance of 'process' in Rethinking Project Management: the story of a UK government-funded research network. International Journal of Project Management, 24, 650-662 